\title{
THE LINGUISTIC AND STYLISTIC ASPECT \\ OF THE LEXICAL SYNONYMICS (ON THE MATERIAL \\ OF MODERN UKRAINIAN FEMALE PROSE)
}

\section{ЛІНГВОСТИЛІСТИЧНИЙ АСПЕКТ \\ ЛЕКСИЧНОЇ СИНОНІМІКИ (НА МАТЕРІАЛІ \\ СУЧАСНОЇ УКРАЇНСЬКОЇ ЖІНОЧОЇ ПРОЗИ)}

\section{Ludmila Semak ${ }^{1}$}

DOI: https://doi.org/10.30525/978-9934-26-051-3-7

Abstract. This paper is the first complex research of lexical synonyms as components of the artistic discourse of modern Ukrainian female prose introduced into the field of semantic, linguistic and stylistic analysis.

The scientific novelty of the paper is that for the first time in linguistic and Ukrainian studies the lexical synonymy in modern Ukrainian female prose is comprehensively explored, as a result of which the semantic, linguistic and stylistic features of synonyms are clarified.

The study proves that in the analyzed works lexical synonyms, which express the idiolects of modern Ukrainian female prose writers and constitute a set of expressive and imaging marking means of their language creation, represent a number of semantic, linguistic-stylistic, categories. Which allows interpreting them not only in the functional-semantic context but also within linguostylistics.

Modern Ukrainian female prose in Ukrainian literature is the latest holistic socio-cultural phenomenon is represented by the works of such authors as Emma Andiievska, Sophiia Andrukhovych, Nina Bichui, Liuko Dashvar, Oksana Zabuzhko, Kateryna Kalytko, Irena Karpa, Yevhenii Kononenko, Maria Matios and others.

In the paper it is proved that word convergences appear in the literary text because of the special purpose, the purpose set by the authors, therefore they become striking representatives of idiolects of separate masters of prose.

${ }^{1}$ Senior Lecturer at the Department of Philology,

Dnipro State Agrarian and Economic University, Ukraine 
In the paper a detailed analysis of lexical synonyms is carried out, which in the artistic discourse of modern Ukrainian female prose perform a number of basic and additional functions, among which are: functions of differentiation, substitution, aesthetics, synonymic opposition, etc.

Using lexical synonyms in different contexts, prose female writers always carefully weigh the semantic nuances of each word, thus achieving the expressiveness, sophistication and high aesthetic value of their literature.

\section{1. Ветуп}

Сучасна українська жіноча проза, що представлена такими іменами, як Емма Андієвська, Ніна Бічуя, Люко Дашвар, Оксана Забужко, Катерина Калитко, Ірена Карпа, Свгенія Кононенко, Марія Матіос та ін. - об'єкт багатьох досліджень. Зазвичай такий художній феномен опиняється під прискіпливою увагою літературознавців. Питанням виокремлення жіночої прози в загальному літературному процесі, проблемам моделей і наративних стратегій, що їх використовують письменниці для розкриття світоглядно-тематичної сутності творів, концептології жіночої прози, присвятили свої дослідження В. П. Агєєва [1], Т. І. Должикова [9], Н. В. Зборовська [12], Ю. П. Маслова [21], М. Рюткенен [23] та ін.

У лінгвістиці наразі немає праць, у яких здійснено докладний аналіз мови сучасних прозаїкинь. Деякі аспекти стилю жіночого письма висвітлюють такі мовознавці, як І. І. Денисенко [8], Т. І. Должикова [9], В. П. Олексенко [22] та ін. Майже всі дослідники аналізують мову українських письменниць, відштовхуючись від тези, що представники різних статей мають різні уявлення про ті самі реалії дійсності і, відповідно, обирають відмінні мовно-зображальні засоби. Стать у такому контексті зазвичай розуміють не як біологічну, а як сформований соціумом феномен і визначають як гендер. Науковиця М. Рюткенен констатує: «У сучасному мовознавстві гендером називають соціокультурну конструкцію, яка створюється у відношенні до соціокультурної ситуації в суспільстві, що зумовлює одні риси як фемінні, а інші як маскулінні. Ми соціалізуємося в чоловіків і жінок» [23, с. 7]. Така конструкція стає причиною того, що, як зауважує Ю. П. Маслова, «чоловіки і жінки по-різному використовують мову (я говорю таким чином, бо я жінка / чоловік)» [21, с. 101]. На думку М. Рюткенен, «єдність жіночої прози виявляється в так званому гендері» [23, с. 7]. 
Належність людини до певної статі позначена на їі характері, зумовлює або пояснює її вчинки, зрештою, моделює ії індивідуально-мовну картину світу, під якою розуміють індивідуальне усвідомлення фактів навколишньої дійсності та їхніх взаємозв'язків. На думку Г. В. Колшанського, «відображена у свідомості людини мовна картина світу це вторинне існування об'єктивного світу, закріплене й реалізоване у своєрідній матеріальній формі. Цією матеріальною формою є мова, яка й виконує функцію об'єктивізації індивідуальної людської свідомості» [16, с. 15]. У цьому плані значний інтерес становить аналіз текстів / дискурсів, продукованих жінкою або чоловіком, тобто художня дійсність, що створена крізь призму авторського бачення за допомогою індивідуальних лінгвістичних засобів. На думку Т. І. Должикової, «інтерпретація художнього тексту з позицій гендерно маркованих рис $€$ актуальним й перспективним напрямком сучасної лінгвостилістики» $[9$, с. 78]. Першочергового значення набуває дослідження механізму функціонування лексичних одиниць у художньому дискурсі сучасної української жіночої прози з урахуванням їхніх структурно-семантичних, комунікативно-прагматичних і стилістичних особливостей. На матеріалі сучасної української жіночої прози вже проаналізовано мовні засоби вираження емотивності, діалектизми, структурно-семантичні типи вставних конструкцій тощо. Загалом не дослідженим є лексико-синонімічний рівень художнього дискурсу сучасної української жіночої прози.

Мета наукової праці - лінгвостилістичний аналіз лексичних синонімів, що є семантично й функціонально значущими в художньому дискурсі сучасних українських письменниць.

Поставлена мета зумовила потребу виконати такі завдання:

1) синтезувати лінгвістичні дослідження лексичної синоніміки у вітчизняному й зарубіжному мовознавстві;

2) описати лексичні синоніми, що маркують художній дискурс прозаїкинь;

3) дослідити функції словозближень у художньому дискурсі.

Об'єкт дослідження - лексичні синоніми у мові сучасних українських прозаїкинь.

Предмет аналізу - функціонально-стилістичні особливості словозближень у мовотворчості українських письменниць. 
Методи дослідження. У розвідці використано загальнонаукові методи спостереження, аналізу й синтезу, а також описовий метод - для витлумачення сутності явища близькозначності; дистрибутивний метод, доцільний для характеристики сполучуваності лексичних синонімів; метод контекстуального аналізу, що дав змогу прокоментувати виражальні можливості словозближень; метод лінгвостилістичного аналізу, що сприяв 3'ясуванню стилістичних функцій синонімів, виявленню їхньої специфіки в лінійному контексті творів письменниць.

Джерельною базою праці слугували казки «Казка про гадюку й орла, або невдячного приятеля» [2], «Казка про упиреня, що живилося людською волею» [3] Емми Андієвської, роман «Фелікс Австрія» [4] Софії Андрухович, психологічна повість «Шпага Славка Беркути» [5] Ніни Бічуї, роман «Мати все» [7] Люко Дашвар, роман «Музей покинутих секретів» [10] Оксани Забужко, збірка «Земля загублених, або Маленькі страшні казки» [13] Катерини Калитко, роман «Піца «Гімалаї» [14] Ірени Карпи, психологічний роман-детектив «Зрада (Zrada, made in Ukraine)» [17] і новели збірки «Книгарня «Шок» [18] Свгенії Кононенко, роман «Чотири пори життя» [20] Марії Матіос, оскільки мову цих прозових творів маркують численні словозближення, що потребують докладних коментарів.

Новизна наукової розвідки полягає в тому, що в ній уперше в лінгвоукраїністиці комплексно досліджено лексичні синоніми у мовотворчості сучасних українських письменниць, унаслідок чого з'ясовано семантичні й лінгвостилістичні особливості словозближень. Узагальнення та висновки, зроблені в праці, поглиблюють теорію лінгвостилістики, семантики, оскільки дають змогу розширити коло питань, пов'язаних з усебічним дослідженням художнього стилю української літературної мови.

\section{2. Лінгвостилістичний аспект словозближень}

Наукові напрацювання $[16 ; 22 ; 25]$ наразі дають змогу трактувати лексичну синонімію як мовну категорію, що через зближення значень слів реалізує індивідуальну свідомість і пізнавальну діяльність носія мови. Загальний огляд праць, у яких висвітлено проблеми синонімії, переконує в тому, що на сучасному етапі розвитку лінгвоукраїністики дослідження лексичної синоніміки потребує комплексного синтезованого аналізу, що враховує семантичний і стилістичний аспекти синонімів. 
Мистецькі твори сучасних письменниць засвідчують вправне володіння синонімікою української мови. Л. В. Терещенко зауважує: «Щоб додати текстам виразності та емоційності, авторки добирають замість традиційно доречних у конкретній ситуації слів незвичні, на перший погляд, синоніми, збільшуючи таким чином концентрацію закладених характеристик» [25, с. 281]. Через неординарне слововживання прозаїкині створюють враження особливої комунікації, що дає змогу виразно й переконливо передати художню дійсність, змалювати образи й ситуації. Усього цього досягають не стільки багатством лексичного ресурсу, скільки якісним підходом до слова, а також, як наголошує I. I. Денисенко, «вдалим добором значень та смислових і стилістичних відтінків слова, тобто майстерним використанням синонімічних засобів і можливостей загальнонародної мови» [8, с. 191].

У художньому тексті сучасної української жіночої прози натрапляємо на численні лексичні синоніми, що формують особливу манеру висловлення. Лексичні синоніми в художньому дискурсі сучасної української жіночої прози найвиразніші в тому разі, коли постають як:

1. Слова, що відрізняються відтінками в основному лексичному значенні, тобто відбивають різний ступінь вияву ознаки: I тато залюбки хрупав смачні, солодкі сухарики: тато великий, сильний, мужній, найсильніший у світі - з ним нічого не може трапитися... тато випробовував літаки [5, с. 6]. Синонімами у наведеному реченні є слововживання великий, сильний, мужній зі спільним значенням «який має силу і твердий характер». Усі виділені лексеми мають розгалужену семантику. У структурі основного лексичного значення кожного синоніма вже були закріплені потенційні семи 'особа чоловічої статі', 'велика фізична сила', 'сильний характер', 'розвиненість', 'загартованість', 'влада', що стали інтегральною основою для словозближення в контексті. Диференційними семантичними відтінками, що зумовили особливості функціонування лексем, є 'статева належність', 'зміст ознаки', 'величина', 'міра вияву ознаки'.

2. Слова, що мають відмінні експресивно-емоційні оцінки: Хоч скільки він (орел) кидався на здобич, усе чомусь вислизало з пазурів, $i$ того дня змучений, голодний і обшарпаний орел явився до гадюки без гостиния [2, с. 69]. У контексті виділені слова розвинули спільне значення «який вибився із сил» на основі інтегральної семи 'занедбаний 
вигляд’. Слововживання мають різні оцінні відтінки, оскільки змучений є лексемою з нейтральним значенням, тоді як обшарпаний відбиває зневажливе ставлення.

3. Слова, що зближуються значеннями й одночасно відрізняються семантичними відтінками та стилістичними потенціями: Всяка загай$\kappa a$, моняння й потуги пояснити, яка ти насправді хороша, автоматично роблять тебе співучасницею твоїх нападників, щуе заки встигаєш перевести дух [10, с. 283]. Авторський новотвір моняння, очевидно, має індивідуально-авторське значення «намагання щось зробити», а лексема потуги передає семантику «відчайдушна спроба здійснити щось». Виділені іменники реалізують у реченні спільне значення «дія, для виконання якої докладають великих зусиль», що постало на основі архісеми 'дія', інтегральної семи 'наполеглива дія'. Такі синоніми вступають в особливий тип семантичних відношень 3 актуалізацією поняття індивідуально-стильової норми.

4. Слова, що зближуються семантичними відтінками за певних комунікативних умов: Про це він думав $i$ згодом, але вже значно чіткіше i свідоміме [5, с. 14]. Виділені прислівникові слововживання, семантично підпорядковані дієслову думав, синонімізуються внаслідок набуття спільної семи 'зрозуміло, цілком ясно'.

5. Контекстуально поєднані значеннями слова, одне 3 яких є авторським новотвором: Батькова квартира була незатишна $i$ забарложена [5, с. 32]. Авторський неологізм забарложена, утворений від іменника барліг, що в одному з похідних значень вказує на неохайне, переповнене зайвим житло, разом із слововживанням незатишна набули в проілюстрованому контексті спільного значення «незручне для життя чи перебування приміщення».

У сучасному мовознавстві домінує функціонально-семантичний напрям дослідження слів, зокрема й синонімів, метою якого є синхронне вивчення функціонування семантики одиниць лексико-синонімічної парадигми. М. П. Фабіан зауважує, що «за такого підходу вивчають семантичну фіксацію слова в процесі спілкування й експліцитно визначають його семантику через сукупність потенційних типових сполучень, де зафіксоване дане слово» [26, с. 7]. На думку В. В. Красавіної, саме функціональний підхід до вивчення синонімії дає змогу «включати в синонімічний ряд не лише слова у своєму 
прямому значенні, але й ті, що називають одне й те ж саме поняття об'єктивної дійсності у своєму вторинному, переносному значенні» [19, с. 184]. Наприклад, у реченні Дістатися до нашого міста означало врятуватися, його стіни були міцні й неприступні - об иі скелі розбилося вже так багато штурмів, а ще більще було попереду $[13$, с. 7] контекстуальні атрибутивні синоніми міцні й неприступні у зв'язку зі слововживанням стіни, яке вони пояснюють, мають спільне значення «який добре укріплений; захищений».

Функціональна семантика сьогодні націлює дослідників на вивчення лексичного значення синонімів не як ізольованих слів, а як органічних елементів системи мови й вияву мовної діяльності. Проте вона й досі позначена недостатнім розробленням проблем у межах синонімології у зв'язку з появою відносно нових галузей мовознавства та завдяки посиленому інтересу науковців до вивчення прагматичного аспекту людської мови. На думку М. Т. Гаїбової, «розгляд динамічного процесу функціонування лінгвальних одиниць виводить на перший план такі одиниці комунікації, як мовленнєвий акт, висловлення, текст (дискурс). Поняттєвий апарат, розроблений для студіювання цих мовно-комунікативних одиниць у лінгвопрагматиці та інших науках, можна успішно застосовувати під час дослідження художньої літератури» [6, с. 11].

Отже, опис лексичних синонімів, що маркують художній дискурс сучасної української жіночої прози, насправді потребує залучення лінгвостилістичного аналізу, що дасть змогу вивчити водночас і їх семантичне наповнення.

Лексичні синоніми, як зауважує В. В. Красавіна, «демонструють розвиток української літературної мови, а також відображають специфіку індивідуально-авторського мовного стилю митця» [19, с. 185]. Аналіз лексичних синонімів у художньому тексті називають лінгвостилістичним, якщо він розглядає функціонування словозближень у творчому мовному акті, де вони набувають художньо-естетичної значущості. Лінгвостилістичний аспект аналізу художнього тексту на предмет лексичних синонімів є провідним, оскільки в ньому, на думку В. П. Олексенка, «незважаючи на наявність аналізу ритму, синтаксису тощо, які відіграють важливу роль у формуванні тексту, на першому плані стоїть аналіз лексичних засобів мови як головних «збуджувачів» одиниць образно-понятійного рівня змісту тексту» [22, с. 61]. 
Сучасна лінгвостилістика, що спирається на наукові розвідки останніх десятиліть (зокрема, на монографію «Сучасна українська літературна мова. Стилістика» [24], праці С. Я. Срмоленко [11], А. П. Коваль [15] та ін.), у яких розроблено теоретичне підгрунтя для аналізу мовних одиниць художнього стилю сучасної української мови, наразі актуалізує всебічне вивчення індивідуальних мовостилів письменників і письменниць. Повсякчас об'єктом для лінгвостилістичних досліджень постають лексичні синоніми як особливі зображально-виражальні маркери й ознаки авторської мовотворчості.

Лексичні синоніми вважають показником динамічного поступу як літературної мови загалом, так і мовостилю письменника / письменниці. В. П. Олексенко щодо цього зауважує: «За кожним синонімом стоїть смислова та стилістична своєрідність, тобто тонкі, досить специфічні відтінки. Відрізняючись відтінками значень і стилістичною забарвленістю, синоніми виконують у мові декілька функцій: сприяють точності і ясності висловлювання, фонетично урізноманітнюють мову, обумовлюють різноманітність і багатство мово стилів» [22, с. 63]. Вивчення лексичних синонімів у художніх текстах українських прозаїкинь у лінгвостилістичному аспекті, розкриття особливостей їхньої семантичної трансформації в художньому дискурсі становить значний науковий інтерес, оскільки словозближення в сучасній українській жіночій прозі є найпотужнішою стилістичною категорією.

У мові сучасної української жіночої прози лексичні синоніми посідають особливе місце 3-поміж інших мовних засобів, оскільки вони надають художнім текстам мовно-естетичної виразності, адже кожний синонім має свій смисловий і стилістичний потенціал, оригінальні семантичні обертони. У художні тексти сучасних українських прозаїкинь уведені численні словозближення, що передають індивідуально-авторську манеру письма. Наприклад, багато синонімічних нанизувань містять авторські новотвори, що показово для мовостилів усіх сучасних письменниць: ...іще не знайомих з дезодорантами, зате душно напудрених розсипчастою біллю й ружем, напахчених яким-небудь «Індійським сандалом» ф-ки «Красная Москва» чи, в кращому разі, польським, так само млосно-солодким «Вус тоzе...» на різностайно-хоровому тлі розпареного жіночого поту, вже ніхто не відреставрує, - 
а на знімках, вичепурені й свіжсопричесані, вони иілком уходять за сучасниць Анук Еме... [10, с. 317]; I, як і діти, люди минулого завжди здаються нам наӥвними - в усьому, від костюмів $i$ зачісок до способу думання й почування [10, с. 509]; ...ніби з моєї мами викрутив батарейки саме він-погасив $і$ обабив... [10, с. 23]; Бо справою міста йє пам'ятати: безцільно, безглуздо, безпотрібно й суцілььо, кожним каменем [10, с. 518]. Виділені синоніми сприяють увиразненню змісту висловлень, художньо-естетичному зображенню дійсності.

У структурі стилістичних значень синонімів почасти наявні додаткові конотації, пов’язані $з$ диференціацією «нейтральний стиль» «знижений стиль», «нормативність»-«лайливість», «високий стиль»«розмовний стиль» тощо. Додаткові конотації можуть бути зосереджені і в значенні, що передають слова, зближені на підставі спільного стилістичного забарвлення із заздалегідь закріпленою оцінкою, напр.: - Двоєдушні ви всі і злі, тричі прокляті куркулі! - патетично декламує Адріян [10, с. 700]. Виділені слова синонімізовано з метою передання значення «сповнена гніву й ворожнечі людина». Семантико-смислова близькість слів постала на підставі інтегральної семи 'недоброзичлива лицемірна особа' і спільної негативної конотації, що зосереджена в структурі їхніх значень.

Для мови жіночої прози показовими є протиставлення близькозначних словопоєднань у межах одного лінійного контексту, тобто синонімічна антонімізація. Такі своєрідні антитетичні синоніми пронизують твори усіх письменниць. Наприклад, у реченні з роману О. Забужко ...там була кухня, з своїми казанами й сковорідками, там вступав у гру мій власний кулінарний хист, а цуі марні й безужнткові, призначені вже тільки на смітник (nоn-recyclable!) порізнені друзки чийогось життя, - колись для когось дорогі й сповнені смислу, поки те життя тривало, поки його виповнювала, підсвічуючи зсередини кожну таку дрібничку, жива волога чиєїсь любови [10, с. 117] протиставлення виділених синонімів спирається на абстрактні світовідчуттєві категорії «важливість» / «неважливість».

Лексичні синоніми в художніх текстах сучасної української жіночої прози зазвичай є стилістично та експресивно колоритними, зазнають асоціативного й образно-символічного переосмислення в контексті. Виразовими ознаками мовної практики прозаїкинь по- 
стають словозближення, компонентами яких є емоційно, експресивно й стилістично забарвлена лексика, індивідуально-авторські новотвори. До оригінальних ознак мовостилю письменниць належать ті лексичні синоніми, що в художніх текстах становлять такі стилістичні фігури, як ампліфікащіï, градащзї, париелящії, синонімічні антонімізації тощо та виконують різні стилістичні функції уточнення, деталізації зображення, синонімічного підсилення, протиставлення та ін. Напр.: Іноді ми робили вигляд, щзо дійшли згоди, а потім серед ночі, лежачи поруч в одному ліжку, починали все від початку: ще безжальніше, ще затятіше, щзе безнадійніше [4, с. 13]; Увесь день я металася до телефонної трубки: чи не заклинило, не заблокувало, не відключило? [20, с. 11]. У наведених лінійних контекстах спостережено ампліфікаційні нанизування контекстуальних синонімів, що ущільнюють семантичну або емоційноекспресивну характеристику понять.

Лексичні синоніми увиразнюють контексти, коли утворюють стилістичні фігури - градаціï. Нагромадження синонімів може породжувати поступовий перехід від нижчого ступеня вияву ознаки понять до вищого й навпаки, пор.: Лежу непорушно, ущерть переповнена жаром, сита тобою, сонна, утішена - мало не зомліла, та радісна, радісна, як земля, яку пошкородили борони, $і$ муркочу щзось безтямне $i$ нерозумне, $і$ не соромлюся глупоти і безсилля [20, с. 51].

Виразною ознакою художнього дискурсу сучасної української жіночої прози так само є ситуативно зумовлені синоніми, що передають не лише особливу семантику, а й прагматику, пор.: Колись серед упирів знайшлося таке кволе, малесеньке й слабосиле упиреня, що батьки тяжко зажурилися, зважаючи, чи їхня довгоочікувана дитина взагалі будь-коли ступить у їхній слід, щзоб продовжити славу й гідність упирячого роду [3, с. 33]; ... вибач, серденько, але я не в змозі довше зносити изього отерпу безумної, вселенської ніжности, якою підпливаю, мов кровотечею, цього нутряного, черевного, жнивотинного жалю... [10, с. 23]. Наведені та багато інших словозближень, що маркують лінійні контексти художніх творів прозаїкинь, привертають увагу читача, який має по-своєму розпізнати й усвідомити наміри письменниць щодо контекстуальних синонімів такого зразка. 


\section{3. Функції лексичних синонімів}

Специфічною рисою сучасної лінгвостилістики є функціональний підхід до вивчення мовних одиниць, які формують художній текст, що сприяє пізнанню загальних законів художньо-естетичної творчості та своєрідності ідіолекту того чи того митця / мисткині. Синоніми, як i будь-які інші мовні одиниці, у своєму значенні зосереджують функціонально-стилістичний потенціал, своєрідно реалізований у художньому тексті / дискурсі за авторськими намірами.

Синонімам у художніх творах нерідко властива функціональна разовість, зумовлена індивідуальним характером їньої метафоричної семантики. Наприклад, у лінійному контексті Справа ияя безнадійна, бо причина взаємної нелюбові Іветти і Стаса - Платон - була тотемною $і$ недоторканною [7, с. 9] виділені слова розглядаємо як контекстуальні синоніми, що набувають спільної інтегральної семи 'значущість'. Ситуативно-значеннєве зближення кількох лексем пов'язують 3 їхнім спільним призначенням, тому аналізувати синонімічний рівень сучасної української жіночої прози потрібно не лише з позицій лексичної семантики, а й у межах текстології, лінгвостилістики та інших галузей.

За нашими спостереженнями, у мові сучасної української жіночої прози синоніми найчастіше виконують функцію уточнення, слугують важливим мовностилістичним засобом деталізації зображуваного, де кожне наступне слово в синонімічному ряді дає нову, додаткову інформацію про предмет, його риси чи якості. Роль ситуативних синонімів завжди зумовлена функцією розрізнення, що постає як прагнення авторок виразити різні відтінки поняття. Наприклад: ...аж тут раптом, просто з-під ятки з розкладеними на ній тельбухами випірнула стара, чорна, зморщена бабця з целофановим пакетом у руках [14, с. 45]. Роль уточнення в лінійному контексті відіграють синоніми стара, чорна, зморщена, що їх об'єднує сема 'старість'. Значення лексеми старий уточнено синонімом чорний, тобто такий, що потемнів 3 часом, зморщений, оскільки з віком покрився зморшками.

Роль семантичного підсилення в лінійних контекстах почасти виконують дієслівні синоніми, що протиставлені додатковими семами. Такі словозближення динамізують контекст, підкреслюють емоційність дії, що відбиває й певні психічні риси мисткині: Все щзе не розплющуючи очей, просуваю свої змисли за двері, подумки прослуховую-перевіряю 
коридор, ванну, кухню - скрізь тихо [10, с. 57]. Друге слово уточнює та інтенсифікує значення першого: не просто слухаю, а уважно прослуховую і прискіпливо перевіряю. Своєрідність зазначених якостей дієслівних синонімів слугує для письменниці О. Забужко дієвим засобом характеризації персонажа Дарини, іiі уважного ставлення до діянь, учинків. Синоніми в таких випадках виконують таку саму функцію, як повторення одного слова, вони можуть і сполучатися з повторенням: А кожна найменша частинка щуодень ділиться на чимраз менші, $і$ вони рухаються і кружляють навколо нас, у нас, у всьому, всюди [4, с. 17]. Пізнання й осмислення себе та навколишнього світу героїнею Стефанією Черненько в романі С. Андрухович зображено через вживання синонімічних словосполук навколо нас, у нас, у всьому, всюди. Такі синонімічні конструкції виступають тут текстоформантом.

Функціонування в одному лінійному контексті лексичного повтору й синонімів нерідко зумовлене розрізненням, що постає як потреба увиразнити смислові та стилістичні відтінки поняття, коли кожний наступний синонім деталізує семантику попереднього. У висловленні Він (Ернест Торн) не вийшов із-за лаштунків, не виповз із пагоди, не вислизнув із темряви на сцені. Жодного руху не відбулося, ніщзо не потривожило застояного повітря [4, с. 18] кожний наступний повтор підсилено заперечною часткою не, що додатково інтенсифікує наратив й оприявлює експресивні потенції художнього дискурсу. Багато лінійних контекстів 3 цього роману маркує не одне словозближення. Функціонування в тому самому синтаксичному фрагменті кількох синонімічних рядів підсилює експресію висловлення, дає змогу деталізувати опис художньої дійсності: Вони стримують всередині пружину нетерпіння, повністю готові до того, щзо зараз звідкілясь вистрибне несусвітня проява чи викотиться несказанне чуперадло, випурхне незбагненна дивовижа, станеться циось цілковито немислиме, щзось таке, чого й уявити не можна. І вони повністю до ичього готові, напружені і перелякані, збуджені до краю [4, с. 18]. У висловленні кожне наступне виділене словозближення є уточнювальним. Із наведених синонімічних ситуацій можна вичленити синоніми однієї частиномовної належності й об'єднати їх у такі низки синонімів: вистрибнути, викотитися, випурхнути, статися; несусвітній, несказанний, незбагненний, немислимий; проява, чуперадло, дивовижа, немислиме. 
Враження від прочитаного посилюється уведеним у наступному реченні синонімічним рядом готовий, напружений, переляканий, збуджений, що передає почуття персонажів-глядачів шоу, тим самим збуджуючи відчуття захвату, незбагненності й у читачів.

У мові сучасної української жіночої прози синоніми виконують функцію замімення тоді, коли реалізують можливість передавати відтінки того самого поняття, оскільки для його позначення в мові існує кілька слів. Водночас сама потреба передавати семантичні обертони зумовила появу кількох слів для позначення того самого поняття, тобто спричинила виникнення ідеографічних синонімів. Як зазначають В. П. Олексенко й О. В. Рембецька, «якихось істотних відмінностей в емоційному забарвленні чи стилістичному використанні між ідеографічними синонімами не існує, проте додаткові семантичні відтінки їх часом досить прозорі» [22, с. 64]. Спираючись на такий погляд науковців, уважаємо, що основне призначення ідеографічних синонімів і в мові, і в художньому тексті - служити засобом точного висловлення думки в мовному акті, напр.: Вона (Аделя) знає, щзо я змалку ичікава до природи різних чудес, до того, щзо звуть магією $i$ чародійством ... [4, с. 30]. Лексичні значення наведених синонімів досить близькі, вони відрізняються лише семантичним відтінком 'величина надприродної сили'.

Художні тексти сучасної української жіночої прози подекуди постають плацдармом для успішної реалізації функиії синонімічного протиставлення слів. Досліджуваний матеріал засвідчує, що синоніми в художньому дискурсі прозаїкинь можуть бути протиставлені на семантико-смисловій основі, або за допомогою різних граматичних і синтаксичних засобів: сполучників, заперечних часткок тощо, пор.: 3 Аделею легко $і$ спокійно, а я-криклива $і$ знервована, плачу навіть крізь сон. [...] Це було смішно: ми з Аделею - як небо $і$ земля. Аделя - бліда $і$ напівпрозора, з хмарою русявого волосся, тонкого, як пух, делікатна, мов сніжна бабка зі збитих вершків, замріяна, ранима $і$ тонкосльоза. [...] Я, Стефранія Чорненько - жилава, смаглява і бистра, міцна, як хлоп, зовсім негарна [4, с. 33]. Вимальовуючи контробрази, С. Андрухович уводить мовні одиниці, які на підставі одночасного зближення / протиставлення синонімізують слова делікатна, замріяна, ранима, тонкосльоза і жилава, бистра, міџна. 
У досліджуваних творах синоніми наділені необмеженими стилістичними потенціями, вони постають однією з найвиразніших лінгвоестетичних і лінгвостилістичних категорій. Сучасні письменниці повсякчас демонструють неповторну мовну манеру письма й витончений художній смак. У вертикальному контексті їхньої мовотворчості синоніми, виконуючи естетичну функцію, сприяють створенню особливої - жіночої - милозвучності тексту. Естетизації лінійних контекстів авторки досягають, удаючись до заміщення одних лексичних одиниць іншими в тому разі, якщо слова мають схожі значення, напр.: Посміхнулася так привітно й лагідно, що мати несподівано подумала: синові є за чим так тужити [18, с. 61]; Обвислі повіки майже повністю прикривають вибляклі очі, безбарвні губи луком вигнуті вниз ... [4, с. 34]; Але бачила в них тільки потріскані судини, відчай $і$ жах, біль $i$ провину [4, с. 19]. Функцію заміщення можуть виконувати лише слова, що мають близьке, майже ідентичне смислове наповнення: $п р и$ вітно, лагідно; вибляклий, безбарвний; відчай, жах, біль.

Сучасні українські прозаїкині дуже тонко відчувають семантико-смислові обертони синонімів, функціонування яких у мовно-художній практиці залежить від індивідуальних особливостей формування думки у зв'язному тексті, та в бажанні віднайти найточніший засіб для опису міркувань і відчуттів, напр.: Петро - художник, він живе у світі образів та обрисів, у фактурах, вигинах ізаламуваннях світла [4, с. 35]. Лексеми образ, обрис та вигин, заламування семантично зближені не лише в проілюстрованому синтаксичному сегменті, а й у мовному узусі. Вони загалом є взаємозамінними, тому в повсякденному спілкуванні такі слова не вживають разом в одному висловленні. Утім, у поданому лінійному контексті виділені синоніми розглядаємо як своєрідний авторський прийом, що дає змогу виявити додаткові смислові відтінки зближених слів: 'конкретно-чуттєва форма відображення', 'мистецька дійсніть'. За допомогою цих цілком взаємозамінних слів письменниця описує світ, у якому живе художник, увиразнюючи й естетизуючи висловлення в такий спосіб.

У художньому дискурсі письменниць нерідко помічаємо формальностилістичне урізноманітнення думки за допомогою різностильових синонімів, пор.: [...] i перетворювати иче неприємне, смердюче місиво на бруски твердого мила, щуо дозрівало в довгих дерев'яних формах, 
а потім, порізане на квадратні куби, воно змінювало колір $i$ запах, даючи густу пухнасту піну при контакті з водою [4, с. 32]. Зближення за значенням лайливої лексеми смердючий і нейтральної неприємний надають експресивного забарвлення ситуації, через що увесь фрагмент набуває негативної емоційно-оцінної конотації.

Синоніми виконують естетичну функцію у текстах сучасної української жіночої прози тоді, коли відбивають архітеми мистецьких творів, постають важливим засобом відображення художньо-естетичної дійсності, оприявлюючи оригінальне мовомислення письменниць. У мові художніх творів сучасних українських прозаїкинь синоніми нерідко розширюють багатопланову семантику висловлень, наповнюють зміст твору неординарними символами й асоціаціями. У такий спосіб збагачується й розширюється семантична структура багатьох лексем, які зближуються в лінійних контекстах, набуваючи нових відтінків у своїх значеннях, що не є притаманними для узуального мовного спілкування.

Утім, авторки частіше заглиблюють читачів у звичне, наповнене багатьма проблемами життя пересічних людей. Наприклад: $3 a$ n'ять хвилин Ангеліна зачинила за білявкою двері, прибігла до вітальні-розбурхана, обурена [7, с. 44]; Ще довго в кухні товклися. Приголомшені, розбурхані, безсилі... [7, с. 67]. Лексеми розбурханий, обурений, приголомшений, безсилий, що функціонують у проілюстрованих індивідуально-авторських висловленнях, дають змогу передати важкий стан героїв, їхні відповідні відчуття й міркування. Виділені слововживання кваліфікуємо як контекстуальні синоніми, що зблизилися своїми значеннями на основі спільної інтегральної семи 'пригнічений стан'. Ущільнення контекстів у такий спосіб слугує емоційному увиразненню художньої оповіді, додає до їі змісту важливих семантичних відтінків - динамізму й різкості.

Помічаємо зближення слів знишувати, проникати, розкидати, кипіти, виплескуватися, вивертати, катувати в таких лінійних контекстах: Та цього чорного осіннього вечора, коли вітер невблаганно зницував найменші острівиі спокою, проникав у саму душу, нутрував $у$ ній, розкидав думки, вишукуючи найпотаємнішу, а знайшовщи, кидав у дощ, щуоб той змив геть усі намарування вагань і сумнівів, залишив тільки прагматичний факт, чи, навпаки, потопив факт і залитив 
самі вагання і сумніви - коли Стас пойхав, так і не дочекавиись вагітної дружини... [7, с. 44]; Кипів-виплескувався, без слів кричав: «Як?! Це гидке створіння не бажає виходити?!» [7, с. 15]; Вивертала-катувала - звідки такі думки? Звідки? [7, с. 34]. Усі ситуативні синоніми, крім архісеми 'дія', мають значеннєвий компонент 'руйнація', 'приниження'. Наведені словозближення змушують читача перейнятися неспокоєм, тривогою. Виділені ряди продовжено оказіональним синонімом нутрувати, щоб якомога глибше передати настрій, примусити читача відчути моторошність і відразу від такої дії.

Функцію відтворення емоційно-оцінного ставлення персонажів синоніми можуть реалізувати через вирівнювання плану оповіді в змістовому та стилістичному аспектах, напр.: Відтак цее все скрутилося 8 готичну вежу, вежа поповзла ще догори, як змія чи осока в водi, а тод $i$ потемніла. I все стало теплим, затишним і спокійним [14, с. 78]. Лексеми теплий, затишний, спокійний, об'єднані значенням «стан, сповнений тиші, приємний для перебування в ньому», передають суб'єктивне ставлення персонажа до навколишньої дійсності.

До допоміжних ролей синонімів зараховуємо функцію характеризації героїв, персонажів, образів, описів, напр.: I наснилося йому - сон був дуже виразний: не каламутний, не диспропорційний, як воно часто буває у снах, - снилося йому русяве волосся жінки на його подушиі $[18$, с. 52]. Проілюстровані слова синонімізувалися на підставі архісеми 'ознака' та за рахунок актуалізації інтегральної семи 'чіткий вияв ознаки’, що є компонентами лексичного значення «який зовнішніми ознаками ясно передає внутрішні якості».

Функцію індивідуалізації художніх образів виконують, наприклад, синоніми в реченні Була би Редька нормальною, свідомою, газдівською дитиною з Івано-Франківської області, то так би ї̈ тут $і$ бачили 3 iï шенгеном [14, с. 79]. Перше слово виділеного синонімічного ряду закономірно моделює семантику двох наступних слів, актуалізуючи у структурі їхніх лексичних значень інтегральну сему 'відповідність системі поглядів’. Доповнюючи ряд синонімом-діалектизмом газдівський і локативною обставиною з Івано-Франківської області, I. Карпа надає позитивної оцінки синонімічному ряду, а отже, і персонажеві, оскільки газдівський у національно-ментальній свідомості українця завжди має схвальну конотацію. 
Словозближення стають істотним компонентом загальної образно-символічної системи прозових творів письменниць. Частотність уживання контекстуально синонімічних одиниць у мовній практиці підпорядкована комунікативно-стилістичним завданням. Одним із постійних джерел поповнення синонімічних рядів у творах письменниць $\epsilon$ тропеїчне, передусім метафоричне, вживання слів, напр.: Але поки щзо мерехтіння дрібного снігу заворожує $і$ зваблює шукати якийсь додатковий вимір у сірому просторі знайомих вулиць [17, с. 61]. Виділені слововживання мають спільне значення «навмисно діяти з наміром викликати привабливість». Якщо для дієслова зваблювати таке значення $\epsilon$ прямим, то для заворожувати - метафоричним, оскільки в загальномовній практиці вживання слово заворожувати означає «перен. зачаровувати, захоплювати».

\section{4. Висновки}

Отже, комплексне вивчення лексичних синонімів у мові сучасної української жіночої прози дає змогу, з одного боку, всебічно проаналізувати їхню семантику, функціональний потенціал, а $з$ другого - простежити механізм сприйняття стилістично маркованих словозближень читачами. Зокрема, уведення лексичних синонімів як виражально-зображальних засобів творчої мовної манери письменниць у функціонально-семантичну й лінгвостилістичну площину їхнього аналізу сприяє з'ясуванню основних засобів впливу авторського тексту на читачів, які по-своєму сприймають та осмислюють авторські інтенції, що зафіксовані в художньому тексті та допомагають трансформувати його в дискурс.

Сучасна українська жіноча проза органічно «вписується» у соціально-психологічні, філософські та етичні координати сучасного життя, але особливий інтерес становить жіночий мовостиль, творча манера авторок, їхнє вміння з винятковою тонкістю, вишуканістю поєднати слова, зближуючи їх тими чи тими значеннєвими відтінками. Такі контекстуально оприявлені зближення багатьох лексем $є$ не випадковими, вони зумовлені призначенням, метою, що їх ставлять перед собою прозаїкині, функціями, якими письменниці наділяють синоніми в різних контекстах. У мовній тканині творів сучасної української жіночої прози синоніми виконують функції розрізнення, заміщення, синоні- 
мічного протиставлення й естетизації. Утім, стилістичний потенціал синонімів не обмежений визначеними функціями, оскільки в межах багатьох лінійних контекстів близькозначні слова постають як нові, миттєві, непередбачені словопоєднання.

\section{Список літератури:}

1. Агеєва В. (2003). Жінка-читач і жінка-автор у постсоцреалістичній літературі: [творчість О. Забужко, Є. Кононенко, Г. Пагутяк, С. Касьянової]. Жіночий простір. Феміністичний дискурс украӥнського модернізму. Київ: 277-284.

2. Андієвська Е. (2019). Казка про гадюку й орла, або невдячного приятеля. Казка про яян; Говорюща риба : казки. Київ: 68-76.

3. Андієвська Е. (2019). Казка про упиреня, що живилося людською волею. Казка про яян; Говорюща риба : казки. Київ: 33-39.

4. Андрухович С. (2014). Фелікс Австрія. Львів: 288.

5. Бічуя Н. (2010). Шпага Славка Беркути. Львів: 176.

6. Гаибова М. Т. (1986). Прагмалингвистический анализ художественного текста. Баку: 88.

7. Дашвар Л. (2010). Мати все. Київ: 258.

8. Денисенко I. I. (2013). Характеристика явища лексичної синонімії у творі О. Забужко «Notre Dame d'Ukraine: Українка в конфлікті міфологій». Наукові записки НДУ ім. М. Гоголя. Філологічні науки. Книга 1: 187-191.

9. Должикова Т. І. (2011). Світ жінки у її мові (про лінгвостилістику сучасної фемінної прози). Культура слова. Вип. 75: 73-78.

10. Забужко О. (2020). Музей покинутих секретів : роман. Вид. 7-е, доп. Київ: 832.

11. Єрмоленко С. Я. (2017). Лінгвостилістика в контексті сучасного мовознавства. Мовознавство. № 4: 20-27.

12. Зборовська Н. (2008). Українська література в умовах масової культури : [творчість О. Забужко]. Дивослово. № 4: 47-50.

13. Калитко К. (2019). Земля загублених, або маленькі страшні казки. Львів: 224.

14. Карпа І. Піца «Гімалаї» (2011). Харків: 400.

15. Коваль А. П. (1987). Практична стилістика сучасної української мови. Київ: 352.

16. Колшанский Г. В. (1980). Контекстная семантика. Москва: 152.

17. Кононенко Є. (2002). Зрада. ZRADA made in Ukraine : роман. Львів: 160.

18. Кононенко С. Книгарня «ШОК» (2009). Львів: 128.

19. Красавіна В. В. (2018). Текстуальна синонімія як зображальновиражальний засіб художнього мовлення (на прикладі прози Михайла Коцюбинського). Література та культура Полісся. Серія «Філологічні науки». № 13: 181-193.

20. Матіос М. (2001). Чотири пори життя. Львів: 236.

21. Маслова Ю. П. (2015). Особливості розвитку гендерних лінгвістичних досліджень в Україні й закордоном. Наукові записки Національного університету «Острозька академія». Серія «Філологічна». Вип. 57: 100-105. 
22. Олексенко В. П., Рембецька О. В. (2010). Функційно-стилістичні особливості дієслівних синонімів у творах Уласа Самчука. Вісник Таврійської фундачиї (Осередку вивчення украӥнської діаспори) : літ.-наук. зб. Київ - Херсон: Вип. 7: 60-69.

23. Рюткенен М. (2000). Гендер и литература: проблема «женского письма» и «женского чтения». Филологические науки. № 3: 6-11.

24. Сучасна українська літературна мова: стилістика / за заг. ред. акад. АН УРСР І. К. Білодіда (1973). Київ: 588.

25. Терещенко Л. В. (2004). Лексична синонімія: спроба аналізу функціональної тотожності. Вісник Львівського університету. Серія "Філологічна». Вип. 34. Ч. 1: 280-285.

26. Фабіан М. П. (2014). Семантика мовного етикету: новий підхід до іiі вивчення. Сучасні дослідження з іноземної філології. Вип. 12: 7-13.

\section{References:}

1. Aheieva V. (2003). Zhinka-chytach i zhinka-avtor u postsotsrealistychnii literaturi: [tvorchist O. Zabuzhko, Ye. Kononenko, H. Pahutiak, S. Kasianovoi]. [Female reader and female author in post-socialist literature]. Zhinochyi prostir. Feministychnyi dyskurs ukrainskoho modernizmu. Kyiv: 277-284. (in Ukrainian)

2. Andiievska E. (2019). Kazka pro hadiuku y orla, abo nevdiachnoho pryiatelia [A tale about a viper and an eagle, or an ungrateful friend]. Kazka pro yaian; Hovoriushcha ryba: kazky. Kyiv: 68-76. (in Ukrainian)

3. Andiievska E. (2019). Kazka pro upyrenia, shcho zhyvylosia liudskoiu voleiu [A fairy tale about a ghoul that fed on human will]. Kazka pro yaian; Hovoriushcha ryba: kazky. Kyiv: 33-39. (in Ukrainian)

4. Andrukhovych S. (2014). Feliks Avstriia [Felix Austria]. Lviv: 288. (in Ukrainian)

5. Bichuia N. (2010). Shpaha Slavka Berkuty [Slavko's Berkuta sword]. Lviv: 176. (in Ukrainian)

6. Haybova M. T. (1986). Prahmalynhvystycheskyi analyz khudozhestvennoho teksta [Pragmalinguistic analysis of literary text]. Baku: 88. (in Ukrainian)

7. Dashvar L. (2010). Maty vse [Have everything]. Kyiv: 258. (in Ukrainian)

8. Denysenko I. I. (2013). Kharakterystyka yavyshcha leksychnoi synonimii u tvori O. Zabuzhko «Notre Dame dUkraine: Ukrainka v konflikti mifolohii» [Characteristics of the phenomenon of lexical synonymy in O. Zabuzhko's work «Notre Dame d'Ukraine: Ukrainian woman in the conflict of mythologies»]. Naukovi zapysky NDU im. M. Hoholia. Filolohichni nauky. Knyha 1: 187-191. (in Ukrainian)

9. Dolzhykova T. I. (2011). Svit zhinky u yii movi (pro linhvostylistyku suchasnoi feminnoi prozy) [The world of a woman in her language (on the linguistic style of modern feminine prose)]. Kultura slova. Vol. 75: 73-78. (in Ukrainian)

10. Zabuzhko O. (2020). Muzei pokynutykh sekretiv: roman [Museum of Abandoned Secrets]. Vyd. 7-e, dop. Kyiv: 832. (in Ukrainian)

11. Yermolenko S. Ya. (2017). Linhvostylistyka v konteksti suchasnoho movoznavstva [Linguistic stylistics in the context of modern linguistics]. Movoznavstvo. № 4: 20-27. (in Ukrainian) 
12. Zborovska N. (2008). Ukrainska literatura $\mathrm{v}$ umovakh masovoi kultury: [tvorchist O. Zabuzhko]. [Ukrainian literature in terms of mass culture: [works by O. Zabuzhko]]. Dyvoslovo. № 4: 47-50. (in Ukrainian)

13. Kalytko K. (2019). Zemlia zahublenykh, abo malenki strashni kazky [Land of the Lost, or Little Scary Tales]. Lviv: 224. (in Ukrainian)

14. Karpa I. Pitsa «Himalai» [Himalayan pizza]. (2011). Kharkiv: 400. (in Ukrainian)

15. Koval A. P. (1987). Praktychna stylistyka suchasnoi ukrainskoi movy [Practical stylistics of the modern Ukrainian language]. Kyiv: 352. (in Ukrainian)

16. Kolshanskiy G. V. (1980). Kontekstnaya semantika [Contextual semantics]. Moskva: 152. (in Russian)

17. Kononenko Ye. (2002). Zrada. ZRADA made in Ukraine: roman [The Treason]. Lviv: 160. (in Ukrainian)

18. Kononenko Yevheniia. (2009). Knyharnia «ShOK» [The Bookstore «Shock»]. Lviv: 128. (in Ukrainian)

19. Krasavina V. V. (2018). Tekstualna synonimiia yak zobrazhalnovyrazhalnyi zasib khudozhnoho movlennia (na prykladi prozy Mykhaila Kotsiubynskoho) [Textual synonymy as a pictorial means of artistic speech (on the example of Mikhail Kotsyubynsky's prose)]. Literatura ta kultura Polissia. Seriia «Filolohichni nauky». № 13: 181-193. (in Ukrainian)

20. Matios M. (2001). Chotyry pory zhyttia [Four seasons of life]. Lviv: 236. (in Ukrainian)

21. Maslova Yu. P. (2015). Osoblyvosti rozvytku hendernykh linhvistychnykh doslidzhen v Ukraini y zakordonom [Features of development of gender linguistic researches in Ukraine and abroad]. Naukovi zapysky Natsionalnoho universytetu «Ostrozka akademiia». Seriia «Filolohichna». Vol. 57: 100-105. (in Ukrainian)

22. Oleksenko V. P., Rembetska O. V. (2010). Funktsiino-stylistychni osoblyvosti diieslivnykh synonimiv u tvorakh Ulasa Samchuka [Functional and stylistic features of verb synonyms in the works of Ulas Samchuk]. Visnyk Tavriiskoi fundatsii (Oseredku vyvchennia ukrainskoi diaspory): lit.-nauk. zb. Kyiv - Kherson: Vol. 7: 60-69. (in Ukrainian)

23. Riutkenen M. (2000). Hender y lyteratura: problema «zhenskoho pysma» y «zhenskoho chtenyia» [Gender and literature: the problem of «women's writing» and «women's reading»]. Fylolohycheskye nauky. № 3: 6-11. (in Ukrainian)

24. Suchasna ukrainska literaturna mova: stylistyka [Modern Ukrainian literary language: stylistics] / za zah. red. akad. AN URSR I. K. Bilodida. (1973). Kyiv: 588. (in Ukrainian)

25. Tereshchenko L. V. (2004). Leksychna synonimiia: sproba analizu funktsionalnoi totozhnosti [Lexical synonymy: an attempt to analyze functional identity]. Visnyk Lvivskoho universytetu. Seriia «Filolohichna». Vol. 34. Ch. 1: 280-285. (in Ukrainian)

26. Fabian M. P. (2014). Semantyka movnoho etyketu: novyi pidkhid do yii vyvchennia [Semantics of language etiquette: a new approach to its study]. Suchasni doslidzhennia z inozemnoi filolohii. Vol. 12: 7-13. (in Ukrainian) 